\title{
Analisis Kompetensi Mahasiswa Menjadi Amil Zakat Profesional (Studi Pada Mahasiswa Prodi Manajemen Zakat dan Wakaf IAIN Bengkulu)
}

\section{Competency Analysis of Students Becoming Professional Zakat Amil (Study on Students of Zakat and Waqf Management Study Program IAIN Bengkulu)}

\author{
Yenti Sumarni, Endang Mustika \\ Manajemen Zakat Dan Wakaf \\ Fakultas Ekonomi Dan Bisnis IAIN Bengkulu \\ yentisumarni@gmail.com
}

Manuscript received 18 Oktober 2021, processed 22 Oktober 2021, published 31 Desember 2021

\begin{abstract}
The purpose of this study was to determine the competencies possessed by students of the Zakat and Waqf Management Study Program to become candidates for professional zakat amil, while the types of data used were secondary data and primary data, using a qualitative approach. Based on the results of research and discussion, it can be concluded that the competencies that must be possessed by zakat and waqf management students are mastering the science of zakat fiqh, mastering managerial knowledge about zakat management, namely collection, distribution and utilization and reporting of zakat, amil must also have skills in the IT field and accountability in calculating rakat funds. on the reality in the field that students of zakat and waqf management study programs are already competent in the field of zakat fiqh science but are not yet competent in the field of fundrising practice and zakat information system technology.
\end{abstract}

Keywords: Competence of amil qakat, professional amil zakat, student potential

Abstrak: Tujuan dari penelitian ini adalah untuk mengetahui kompetensi yang dimiliki oleh mahasiswa Program Studi Manajemen Zakat dan Wakaf untuk menjadi calon amil zakat profesional, sedangkan jenis data yang digunakan adalah data sekunder dan data primer, dengan menggunakan pendekatan kualitatif. Berdasarkan hasil penelitian dan pembahasan dapat disimpulkan bahwa kompetensi yang harus dimiliki oleh mahasiswa pengelola zakat dan wakaf adalah menguasai ilmu fiqih zakat, menguasai pengetahuan manajerial tentang pengelolaan zakat yaitu penghimpunan, pendistribusian dan pemanfaatan serta pelaporan. zakat, amil juga harus memiliki skill di bidang IT dan akuntabilitas dalam menghitung dana zakat. pada kenyataan di lapangan bahwa mahasiswa program studi manajemen zakat dan wakaf sudah berkompeten di bidang ilmu fiqih zakat namun belum berkompeten di bidang praktik fundrising dan teknologi sistem informasi zakat.

Kata kunci: Kompetensi amil zakat, profesional amil zakat, potensi mahasiswa

\section{PENDAHULUAN}

Zakat merupakan sebagian harta yang harus dikeluarkan dan diberikan kepada golongan yang berhak menerimanya yaitu golongan 8 asnaf, sebagaimana telah dimaksud dalam Al-Quran dan As-Sunnah. Pengertian zakat dapat dipahami secara singkat yakni harta yang telah mencapai nisab, mewajibkan kepada pemilik harta (muslim) 
untuk memberikan sebagian hartanya kepada orang yang berhak menerimanya (Mustabik) sesuai dengan syariat Islam. Zakat dikeluarkan apabila harta yang dimiliki merupakan harta yang mewajibkan zakat serta telah mencapai nisabnya, sehingga harta tersebut harus diserahkan kepada mustabik atau diserahkan kepada lembaga yang mengurus zakat atau pun orang (imam) yang bertugas untuk memungut zakat.(Yusuf Qardhawi, 2011).

Zakat bagian dari rukun Islam, zakat merupakan wujud ketaatan umat muslim kepada Tuhannya serta merupakan wujud kemanusiaan dengan sesama manusia. Manfaat mengeluarkan zakat untuk mensucikan harta, menghindarkan dari sifat kikir dan tamak sehingga bisa bersyukur atas rejeki yang diperoleh, memupuk rasa solidaritas dan tolong-menolong terhadap sesama umat dalam hal materi dari kebutuhan umum ataupun khusus.

Amil zakat adalah seorang atau himpunan beberapa orang (lembaga) yang ditunjuk dan disahkan oleh pemerintah untuk mengurus zakat. Tugas utama amil adalah memungut zakat dari orang kaya dan menyalurkannya kepada mustabik. Imam zakat/amil zakat harus memenuhi kriteria kelayakan sebagai Amil zakat, serta harus memiliki kompetensii yang sesuai dengan tugasnya, agar pengelolaan zakat dapat dilaksanakan secara maksimal, sehingga antara amil, muzzaki dan mustahik dapat saling terbuka dan percaya. Pendidikan yang sesuai harus dimiliki oleh amil zakat untuk menunjang pekerjaanya, agar amanah, kompeten serta jujur dalam melaksanakan tugasnya. (Hanif Lutfi, 2018)

Kompetensi amil menjadi salah satu isu nasional dalam diskursus pengelolaan zakat di Indonesia. Rendahnya kompetensi amil menjadi salah satu hambatan optimalisasi pengelolaan di Indonesia. Minimnya kompetensi amil zakat yang diakibatkan karena banyak di antara amil zakat yang direkrut dari anggota masyarakat yang tidak memiliki latar belakang pengetahuan atau keahlian tentang pengelolaan zakat, minimnya balas jasa yang diberikan kepada amil yang berakibat daya tawar terhadap tenaga berkualitas dan profesional rendah. Minimnya pengembangan kualitas amil yang berakibat tidak seimbangnya antara tantangan permasalahan dan tuntutan pelaksanaan tugas dengan kemampuan amil.

Kualitas sumber daya manusia pengelola zakat masih kurang baik, kurangnya keterampilan dan penguasaan manajemen dan banyaknya anggapan yang menjadikan pekerjaan amil ini sebagai profesi atau pilihan karier, tapi sebagai pekerjaan sampingan atau pekerjaan paruh waktu, sehingga berdampak pada rendahnya penghimpunan (fundraising) dana zakat oleh organisasi pengelola zakat. Memilih pendidikan yang sesuai dengan lapangan pekerjaan yang akan digeluti merupakan keharusan agar memperoleh tenaga kerja yang kompeten dan profesional, sehingga mampu menghadapi kondisi dan situasi apapun yang ada dilapangan dan di lingkungan pekerjaannya.

( Sutrisno, 2012)

Institut Agama Islam Negeri Bengkulu Fakultas Ekonomi dan Bisnis Islam merupakan salah satu Institusi yang memiliki Prodi Manajemen Zakat dan Wakaf. Yang mana memiliki Profil Lulusan Program Studi sebagai pengelola/ praktisi lembaga zakat dan wakaf, konsultan bidang zakat dan wakaf, peneliti zakat dan wakaf, serta social entrepreneur yang berbudi luhur, unggul kompetitif, kreatif, inovatif, dan berdaya saing, berpengetahuan luas di bidang zakat dan wakaf, berkemampuan melaksanakan tugas secara profesional, amanah, transparan, akuntable, serta bertanggung jawab terhadap pelaksanaan tugasnya yang berlandaskan integrasi keilmuan keislaman dan sains. Manajemen Zakat dan Wakaf I AIN Bengkulu 
tahunnya dan sampai sekarang jumlah mahasiswa sebanyak 225 orang mahasiswa.

Dari sini menunjukan bahwa banyak masyarakat yang memiliki minat. Mahasiswa semester V (lima) sudah di tawarkan mata kuliah yang sudah menjurus untuk menjadikannya berkompeten di bidang zakat dan wakaf khususnya amil zakat. Mahasiswa digembleng secara penuh dan dipersiapkan secara optimal untuk menguasai seluruh kompetensi amil zakat dan mampu menerapkannya diluar ketika turun ke masyarakat.

Fenomena diatas adalah alasan kuat bagi peneliti untuk melakukan sebuah penelitian untuk mengetahui kompetensi mahasiswa Prodi Manajemen Zakat dan Wakaf menjadi amil zakat yang profesional. Karena jika calon tenaga amil zakat masih ragu dengan ilmu dan kemampuannya bagaimana mungkin mereka mampu menjalankan tugasnya sebagai amil yang dipercaya oleh pemerintah dan masyarakat. Ketika mahasiswa belum siap dan matang menghadapi fase ini, kemungkinan besar mereka akan lebih takut untuk menghadapi dunia kerja nyata.

\section{METODE PENELITIAN}

Pada penelitian ini penulisan menggunakan jenis data kualitatif penelitian kulitatif berdasarkan studi kasus dengan melakukan penelitian lapangan (field research). Pendekatan penelitian ini ialah pendekatan khusus yang dibuat secara deskriptif normatif. Informan yang diambil menggunakan teknik purposive sampling. Sumber data yang diambil dalam penelitian berdasarkan dua jenis data yaitu: Data primer dan data sekunder. teknik pengumpulan data yang dilakukan adalah observasi, wawancara, dan dokumentasi. Teknik analisiss data dilakukan untuk mengolah data-data yang diperoleh dari penelitian dan menjawab rumusan masalah yang telah dirumuskan, Ada dua teknik analisis data yang digunakan pada penelitian ini, yaitu: data reducation, dan conclusing drawing / verification.

\section{HASIL PENELITIAN DAN PEM BAHASAN}

\section{Kompetensi dan Syarat-Syarat Amil Zakat Profesional di Indonesia.}

Berdasarkan hasil penelitian kompetensi dan syarat-syarat amil zakat yang profesional yaitu menguasai ilmu tentang hukum-hukum zakat baik itu UndangUndang, Peraturan Daerah, Peraturan Pemerintah, Peraturan Badan Amil Zakat Nasional dan Ayat Al-Qur'an mengenai pengelolaan zakat serta ketentuan-ketentuan mengenai zakat yang mencakup jenis-jenis zakat, harta wajib berzakat, haul dan nisab, golongan delapan asnaf, menguasai manajemen pengelolaan zakat yaitu perencanaan, pelaksanaan, dan pengorganisasian dalam pengumpulan, pendistribusian dan pendayagunaan zakat, jujur, dan mengikuti sertifikasi amil zakat.

\section{Potensi Mahasiswa Prodi Manajemen Zakat dan Wakaf Menjadi Calon Amil Zakat.}

Berdasarkan hasil penelitian dengan mahasiswa Prodi Manajemen Zakat dan Wakaf, mahasiswa sudah memahami ilmu tentang hukum-hukum zakat seperti AyatAyat Al-Qur'an tentang zakat serta UndangUndang tentang pengelolaan zakat, syarat harta wajib zakat, jenis-jenis zakat, haul dan nisab, golongan delapan asnaf, dan perhitungan zakat yang harus dikeluarkan oleh muzakki.

Namun ada sebagian mahasiswa yang belum memahami teknik fundraising yang efektif dan modern seperti digital fundraising, yang mana digital fundraising sangat berperan 
untuk mengumpulkan dana zakat di era milenial seperti sekarang, agar dana zakat terkumpul mencapai target dan didistribusikan sesuai peruntukkannya. Dan ada juga sebagian mahasiswa kurang memahami tentang sistem informasi yang dipakai oleh lembaga zakat dalam menginput dan mengelola data, karena tidak adanya pembelajaran secara langsung atau tidak adanya pelajaran praktik tentang sistem aplikasi penginputan data atau sistem informasi zakat dan wakaf di perkuliahan.

Karena kurangnya pemahaman mahasiswa Prodi Manajemen Zakat dan Wakaf di bidang tersebut, menjadikan mereka belum sepenuhnya berkompetensi sedangkan hal ini sangat di butuhkan di lembaga zakat sebagai bukti bahwa mahasiswa sebagai calon amil zakat berkompeten dibidang zakat.

\section{KESIMPULAN}

Berdasarkan hasil penelitian dan pembahasan dapat ditarik kesimpulan Kompetensi dan Syarat-Syarat Amil Zakat Profesional di Indonesia adalah harus menguasai ilmu fikih atau hukum zakat, meguasai ilmu manajerial tentang pengelolaan zakat yaitu penghimpunan, pendistribusian dan pendayagunaan serta pelaporan zakat, amil juga harus memiliki kemampuan dalam bidang IT dan akuntabilitas dalam menghitung dana zakat, beragama islam, jujur, dan harus mengikuti sertifikasi amil zakat.

\section{DAFTAR KEPUSTAKAAN}

Djupri, M. (2016) Kompetensi Amil Dan Fungsionalisasinya Dalam Kelembagaan Zakat (Studi Terbadap Badan Amil Zakat Kota Bengkulu) UIN Sunan Kalijaga: Disertasi, Ilmu Agama Islam.

Hanafi Adi Putranto dan Siti Nur Azizah (2019) "Mengukur kompetensi amil melalui kemampuan menajerial dan profesionalitas di lembaga zakat nurul hayat surabaya" Surabaya: Jurnal Manajemen zakat dan wakaf, vol. 1 nomor 1 .

Hanif Lutfi. (2018) Siapakah Amil Zakat?. Jakarta Selatan : Rumah Fiqih Publising.cet:1.

Qardhawi, Yusuf. (2004) Hukum Zakat: Studi Komparatif Mengenai Status dan Filsafat Zakat. Bogor: AntarNusa, Cet. ke-7.

Sutrisno, E. (2012) Manajemen Sumber Daya Manusia. Kencana.

Undang-Undang Nomor 23 tahun 2011 Tentang Pengelolaan Zakat.

Fatwa Majelis Ulama Indonesia No. 8 tahun 2011. Amil Zakat.

Baznas RI. Peraturan Badan Amil Zakat Nasional No. 1 Tahun 2018 Tentang Kode Etik Amil

Baznas RI. Peraturan Badan Amil Zakat Nasional Nomor 2 Tabun 2018

\footnotetext{
14 Analisis Kompetensi Mahasiswa Menjadi Amil Zakat Profesional (Studi Pada Mahasiswa Prodi Manajemen Zakat dan Wakaf IAISNBengkulu
} 